Original Article

\title{
Investigation the effects of vitreous humor on proliferation and dedifferentiation of differentiated NTERA2 cells
}

\author{
Investigar os efeitos do humor vítreo na proliferação e desdiferenciação de células \\ NTERA2 diferenciadas
}

\author{
Z. Rezaeian ${ }^{a *}$ (D), A. R. Bahramia, ${ }^{\mathrm{a}, \mathrm{b}}$, M. M. Matinª and S. S. Hosseiny ${ }^{\mathrm{a}}$
}

aFerdowsi University of Mashhad, Institute of Biotechnology, Cellular and Molecular Biotechnology Research Group, Mashhad, Iran 'Ferdowsi University of Mashhad, Faculty of Sciences, Department of Biology, Mashhad, Iran

\begin{abstract}
Mammals have a limited capacity to regenerate their tissues and organs. One of the mechanisms associated with natural regeneration is dedifferentiation. Several small molecules such as vitamin $C$ and growth factors could improve reprogramming efficiency. In this study, the NTERA2-D1 (NT2) cells were induced towards differentiation (NT2-RA) with $10^{-5} \mathrm{M}$ retinoic acid (RA) for three days and then subjected to various amounts of vitreous humor (VH). Results show that the growth rate of these cells was reduced, while this rate was partly restored upon treatment with VH (NT2-RA-VH). Cell cycle analysis with PI method also showed that the numbers of cells at the S phase of the cell cycle in these cells were increased. The levels of SSEA3 and TRA-1-81 antigens in NT2-RA were dropped but they increased in NT2- RA-VH to a level similar to the NT2 cells. The level of SSEA1 had an opposite pattern. Expression of OCT4 gene dropped after RA treatment, but it was recovered in NT2-RA-VH cells. In conclusion, we suggest $\mathrm{VH}$ as a potent mixture for improving the cellular reprogramming leading to dedifferentiation.
\end{abstract}

Keywords: dedifferentiation, NTERA2, proliferation, vitreous humor.

\begin{abstract}
Resumo
Os mamíferos têm uma capacidade limitada de regenerar seus tecidos e órgãos. Um dos mecanismos associados à regeneração natural é a desdiferenciação. Várias moléculas pequenas, como vitamina $\mathrm{C}$ e fatores de crescimento, podem melhorar a eficiência da reprogramação. Neste estudo, as células NTERA2-D1 (NT2) foram induzidas à diferenciação (NT2-RA) com ácido retinóico (RA) 10-5 M por três dias e depois submetidas a várias quantidades de humor vítreo $(\mathrm{VH})$. Os resultados mostram que a taxa de crescimento dessas células foi reduzida, enquanto essa taxa foi parcialmente restaurada após o tratamento com VH (NT2-RA-VH). A análise do ciclo celular com o método PI também mostrou que o número de células na fase $S$ do ciclo celular nessas células estava aumentado. Os níveis de antígenos SSEA3 e TRA-1-81 em NT2-RA diminuíram, mas aumentaram em NT2-RA-VH a um nível semelhante ao das células NT2. O nível de SSEA1 teve um padrão oposto. A expressão do gene OCT4 diminuiu após o tratamento com AR, mas foi recuperado em células NT2-RA-VH. Em conclusão, sugerimos o VH como uma mistura potente para melhorar a reprogramação celular levando à desdiferenciação.
\end{abstract}

Palavras-chave: desdiferenciação, NTERA2, proliferação, humor vítreo.

\section{Introduction}

Mammals have a limited capacity to regenerate their tissues. Tissue regeneration can be occurred either through the activation of somatic stem cells, located in a niche or by inducing proliferation of the differentiated cells. Some other vertebrates, however show more extensive regenerative capacities than mammals. In certain cases, this potential would lead to complete replacement of limb (Dean 2015). Reprogramming of differentiated somatic cells to be adverted to their pluripotent state is a favorable approach in regenerative medicine. Generation of reprogrammed somatic cells was first demonstrated in mammals by somatic cell nuclear transfer (SCN) technology (Hara et al., 2016; Mizutani et al., 2016; Rao et al., 2015). Embryonic stem (ES) cells, embryonal carcinoma (EC) cells and embryonic germ (EG) cells can induce nuclear reprogramming after their hybridization with somatic cells (Jaenisch and Hochedlinger, 2015; Pfeiffer et al., 2013; Wang et al., 2016; Xu et al., 2016). Takahashi and Yamanaka in 2006 (Takahashi and Yamanaka, 2006) showed that over-expression of 4 genes (Oct4, Sox2, $c-M y c$, and Klf4) in mouse embryonic fibroblasts (MEFs), changed the properties of the cells in favor of embryonic

*e-mail: Zhrrezaiyan4@gmail.com

Received: March 22, 2021 - Accepted: September 19, 2021 
stem (ES) cell properties. These cells were designated as induced Pluripotent Stem (iPS) cells (Hockemeyer and Jaenisch, 2016; Jaenisch and Hochedlinger, 2015; Wernig et al., 2007). Nonetheless, the use of iPS cells in a clinical setting have several limitations (Takahashi and Yamanaka 2013). Development of reprogramming methods without altering the genetic content of the reprogrammed cells would be of certain value. Recently, several small molecules and growth factors have been identified that greatly improve reprogramming efficiency (reviewed in Feng et al., 2009). Valproic acid (VPA), a histone deacetylase inhibitor; BIX01294, an inhibitor of the G9a histone methyl-transferase; RG108 and AZA, DNA methyltransferase (DNMT) inhibitors; and Tranylcypromine, an inhibitor of lysine-specific demethylase 1 are some of epigenetic regulating factors (Li et al., 2016, 2009). Vitamin $C$ is a natural compound that is vital to human health. The discovery of vitamin $C$ as a reprogramming enhancer arose from a metabolic study of the reprogramming process (Eid and Abdel-Rehim, 2016).

One of the mechanisms associated with natural regeneration is dedifferentiation. Dedifferentiation involves a terminally differentiated cell reverting back to a less differentiated stage from within its own lineage that allows the cell to proliferate again before redifferentiation. This process would lead to replacement of the lost cells. We have previously shown that application of $\mathrm{VH}$ to the experimental wounds improves the healing process efficiently in mammalian animals (unpublished data). This study is first step in examining the possible mechanism responsible for this property. Therefore this study sought to investigate the impact of the rabbit $\mathrm{VH}$ on proliferation, cell cycling, and self-renewal specific markers' expression in the model cells of NTERA2.

\section{Materials and Methods}

\subsection{Culture of NTERA2 cells}

NTERA2 clone D1 (NT2/D1) is a hEC cell line, derived from the testicular teratocarcinoma (Andrews et al., 1984) and closely resemble to hES cells and the inner cell mass of human blastocyst stage embryos. The NTERA2 cells were grown in Dulbecco's Modified Eagles Medium (DMEM) supplied with $10 \%$ fetal bovine serum (FBS), $100 \mathrm{U} / \mathrm{ml}$ penicillin, and $100 \mu \mathrm{g} / \mathrm{ml}$ streptomycin (all supplied by Gibco). These cells were kept at $37^{\circ} \mathrm{C}$ and $10 \% \mathrm{CO} 2$ in the air. For passage, the NT2 cells were scraped by glass beads and reseeded $1: 2$.

\subsection{Vitreous humor extraction}

All the animal experiments were performed in accordance to the guide lines from bioethics committee of Ferdowsi University of Mashhad (FUM). Seven skeletally mature male, New Zealand white rabbits (age, 1 year, weight $2.5-3 \mathrm{~kg}$ ) were purchased from Razi Institute, Mashhad, Iran. They were kept in soft bedding cages with free access to food and water. The vitreous humor was sucked out from the dorsal part of eyes using a fine syringe. Each extract, was filter-sterilized using the standard micro filters $(0.22 \mu \mathrm{m})$, and stored in a sterile microtube at $-20{ }^{\circ} \mathrm{C}$ for further use.

\subsection{Retinoic acid (RA) treatment of NTERA2 cells}

NTERA2 cells were seeded at a density of $10^{6}$ cells per T25 flask and treated with RA $\left(10^{-5} \mathrm{M}\right) .5 \mu \mathrm{l}$ of the stock solution $\left(10^{-2} \mathrm{M}\right)$ of RA solution was added to one T25 flask with $5 \mathrm{ml}$ working DMEM for 3 days.

\subsection{Cell cycle analysis}

Cell cycle analysis was performed using direct counting of the cell numbers and also flow cytometry method using Propidium Iodide (PI) as fluorescence reagent. In this study NT2 cells at approximately $65 \%$ confluency were induced towards differentiation (NT2-RA) with $10^{-5} \mathrm{M}$ retinoic acid for three days and then subjected to $7.5 \%$ of the $\mathrm{VH}$ for three and six days and counted by neubauer lam. For PI test, equal amount of NT2, NT2-RA and NT2-RA-VH cells were washed with PBS and centrifuged at $200 \mathrm{x}$ g. After that a hypotonic buffer (50 $\mathrm{mg} / \mathrm{ml}$ propidium iodide in $0.1 \%$ sodium citrate plus $0.1 \%$ Triton X-100; Sigma) was added directly to the cell pellet. The tubes were placed at $4^{\circ} \mathrm{C}$ in the dark overnight before flow cytometric analyses. The propidium iodide fluorescence of individual nuclei was measured in the red fluorescence using a FacScan flow cytometer (Becton Dickinson), and the data were registered in a logarithmic scale.

\subsection{Cell surface antigen analysis}

The cells were detached from culture dish with trypsin/ EDTA. Cell surface antigen expression was assayed by flowcytometry. Briefly, cells were harvested and incubated in primary antibodies for $1 \mathrm{~h}$ at $4^{\circ} \mathrm{C}$. After two washes in wash buffer ( $5 \%$ FCS and $0.02 \%$ sodium aside in magnesium and calcium free Dulbecco's phosphate-buffered saline (PBS), they were incubated in a FITC-conjugated secondary IgM antibody for $1 \mathrm{~h}$. They were then resuspended in wash buffer and analyzed using a Becton Dickinson FacScan flow cytometer. SSEA1, SSEA3 and TRA-1-81 (kindly gifted by Prof. P. W. Andrews, Sheffield University, UK) were the surface antigens that were tested in this research. At the same time P3X63Ag8 (Kohler and Milstein, 1975) was used as a negative control. As these antibodies were raised in mouse, the secondary antibodies for this test were goat anti mouse IgM-FITC.

\subsection{Western blotting}

Cell lysis was performed by modified RIPA buffer ( $50 \mathrm{mM}$ Tris- $\mathrm{HCl}, \mathrm{pH}$ 7.4; $150 \mathrm{mM} \mathrm{NaCl} ; 1 \mathrm{mM}$ phenylmethylsulphonyl fluoride; 1 mM EDTA; $1 \%$ Triton X-100; 1\% sodium deoxycholate; $0.1 \%$ SDS). The concentration of proteins in cell lysates was quantified by means of Bradford assay. Samples were electrophoresed using SDS-PAGE (12\%) and blotted for $2 \mathrm{~h}$ with 100 volt onto PVDF membrane (Amersham Biosciences, Europe $\mathrm{GmbH}$, Germany). Blots were incubated with the anti-OCT4 antibody (SC-5279, Santa Cruz Biotechnology) at dilutions 1:1,000 for $2 \mathrm{~h}$. They were then incubated with the secondary antibody, 
goat anti mouse IgG 2b, at dilutions $1: 5,000$ for $1 \mathrm{~h}$ at room temperature. This membrane was then equilibrated in reaction buffer ( $10 \mathrm{mM}$ Tris- $\mathrm{HCl}, \mathrm{pH} 8.0 ; 150 \mathrm{mM} \mathrm{NaCl}$; and $0.1 \%$ Tween 20 ) at room temperature for $5 \mathrm{~min}$ and used for detection of the protein bands. For detection, the Horseradish Peroxidase and 3, 3-Diaminobenzidine $\mathrm{HCl}$ substrate (DAB) solutions was prepared by adding $0.003 \mathrm{ml}$ of $30 \% \mathrm{H}_{2} \mathrm{O}_{2}$ to $100 \mathrm{ml}$ of DAB substrate $(0.05 \% \mathrm{DAB}$ in reaction buffer made fresh prior to use) and applied onto the equilibrated membrane until the protein bands appear.

\subsection{Statistical analysis}

Descriptive data were summarized as mean and/or percentage. A comparison between groups was performed through the one-way ANOVA. The collected data were analyzed in GraphPad Prism 8.0. P-values less than 0.05 were considered statistically significant. Cell cycle analysis with PI method was measured and analyzed with WinMDI software.

\section{Results}

\subsection{Proliferation and cell cycle analysis}

NT2 cells at approximately $65 \%$ confluency, were treated with RA for three days, and then subjected to $7.5 \% \mathrm{VH}$ and analyzed for the cycling behavior. After 3 and 9 days of seeding, the number of cells were determined by direct cell counting method (Figure 1), and shown that these numbers were considerably higher in the plates receiving VH. Further analysis of their cell cycle was also performed by flow cytometry following propidium iodide treatment (Figure 2 and Table 1). As expected the initial treatment of the cells by RA decreased the number of cells at $S$ phase of the cell cycling. This drop was however reversed back to almost normal figures after treatment with $\mathrm{VH}$ at both time points of 3 and 6 days post treatments, $\mathrm{P}<0.05, \mathrm{P}<0.01$ vs

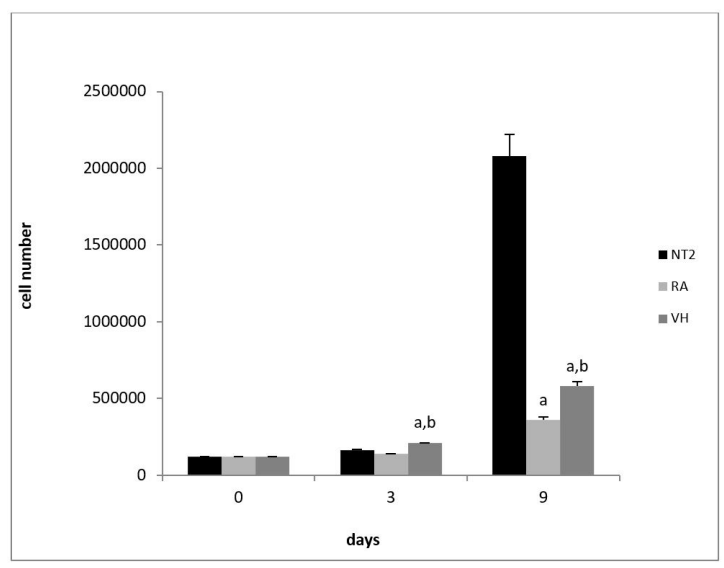

Figure 1. Cell count analysis of NT2, NT2-RA and NT2 RA-VH cells at 3 and 9 days after culturing at 6 well plates. NT2 RA-VH cell numbers were increased in comparison to those of the NT2-RA cells. Data represent the mean \pm SEM. (a) $\mathrm{P}<0.05$; (b) $\mathrm{P}<0.01$ vs control group, compared with NT2-RA cells. control group, compared with NT2-RA cells, respectively (Figure 2 and Table 1).

\subsection{Changes in expression of cell surface antigens}

Result of flow cytometry after Treatment of the NT2 cells with RA showed that expression of SSEA3 and TRA-181 decreased. The level of these antigens, after treatment with $7.5 \%$ and $15 \% \mathrm{VH}$ for 6 days, took a reverse pattern and increased. Expression of SSEA1 after differentiation with RA increased but treatment with $15 \% \mathrm{VH}$ decreased expression of SSEA1 $(\mathrm{P}<0.05)$ (Figure 3 and Table 2 ).

\subsection{Expression analysis of OCT4 protein}

NT2 cells are known as perfectly positive cells for OCT4 protein expression. The NT2 cells, examined by western blot in this experiment followed the same known pattern by expressing OCT4 protein. As expected this level of expression was reduced to undetectable level upon RA treatment. Interestingly these cells managed to recover the expression of the OCT4 protein somehow after receiving VH $(15 \%)(P<0.05)$ (Figure 4).

\section{Discussion}

Previous experiments on mouse ears demonstrated that in wounds treated with $\mathrm{VH}$, fat cell production, angiogenesis, and fibroblast proliferation were increased, leading to a significant increase in tissue regeneration and wound repair (Eming et al., 2014). In another research Yang and his colleagues (Yang et al., 2009) showed that VH, at $20 \%$ concentration, increased the rate of cell proliferation in retinal precursor cells. The $\mathrm{VH}$ contain of many kind of proteins that lead to processes as angiogenesis, cellular proliferation, acute phase response, vascular permeability changes, and oxygen-induced vessel loss (Wang et al., 2012). The dimethylarginine dimethylaminohydrolase (DDAH), gamma-enolase, cytosolic acyl coenzyme A thioester hydrolase and malate dehydrogenase are cellular enzymes, and their levels are all changes in the vitreous of condition, also DDAH is an extremely oxidant-sensitive enzyme. The different expression levels of cytosolic acyl coenzyme A thioester hydrolase and malate dehydrogenase in the $\mathrm{VH}$ could reflect the alterations in glucose and lipid metabolism (Tomita et al., 2021). Our data here are also in line with

Table 1. Cell cycle analysis of NT2-RA cells treated with different concentrations of $\mathrm{VH}$ for 3 and 6 days. The numbers represent percent of the cells at each cycling stages.

\begin{tabular}{ccccccc}
\hline Time & Cycle & NT2 & RA & $\mathbf{2 . 5 \% V H ~}$ & $\mathbf{5 \% V H ~}$ & $\mathbf{7 . 5 \% V H}$ \\
\hline 3 days & G1 & 45 & 59 & 56 & 59 & 56 \\
& S & 11 & 9 & 11 & 12 & 12 \\
& G2 & 33 & 21 & 21 & 19 & 19 \\
6 days & G1 & 58 & 65 & 62 & 62 & 61 \\
& S & 9.5 & 8 & 13 & 11 & 13 \\
& G2 & 17 & 14 & 14 & 15 & 13 \\
\hline
\end{tabular}



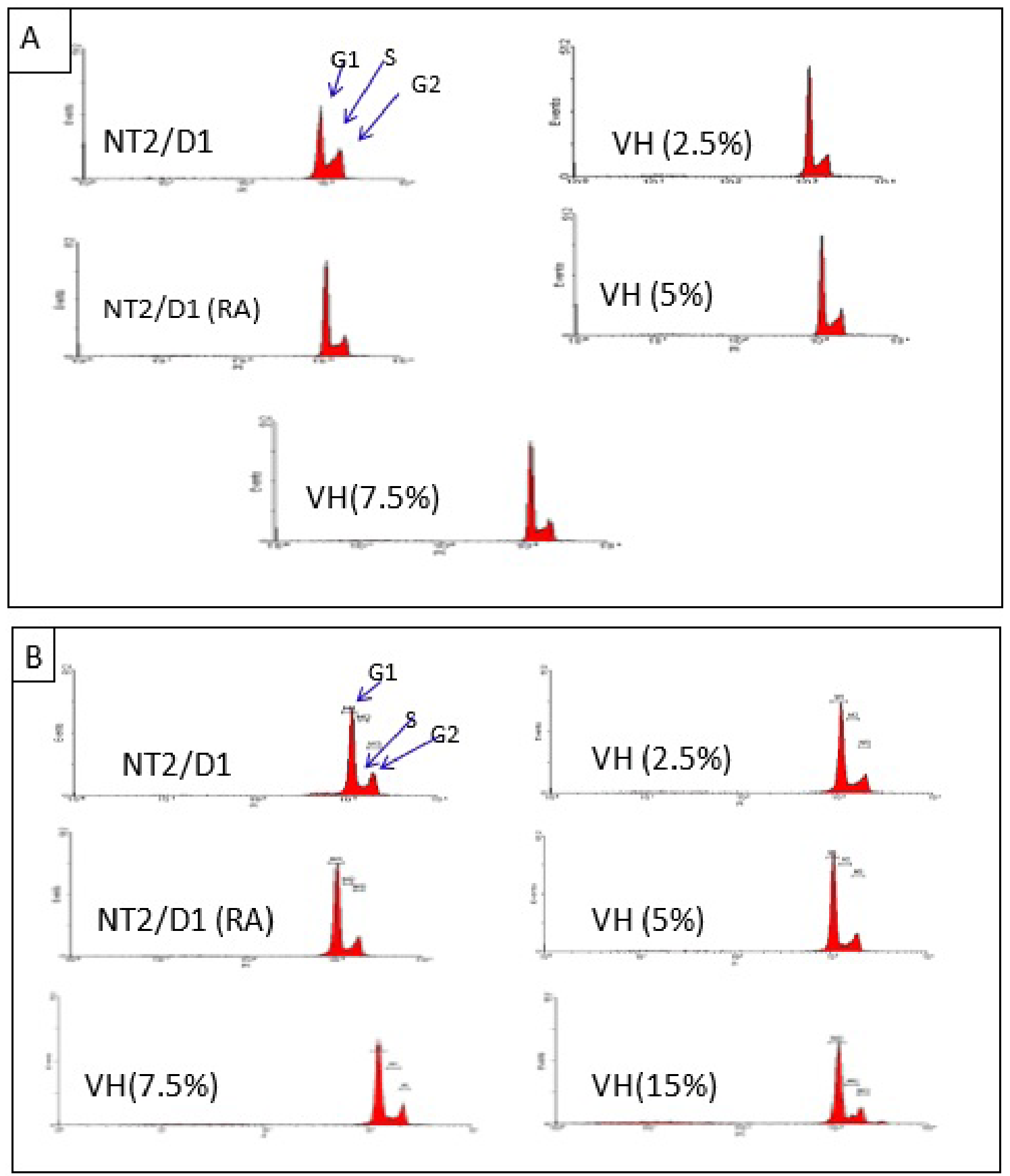

Figure 2. Cell cycle analysis of NT2-RA cells after treatment with different amounts of VH at (A) 3 days and (B) 6 days post-treatment. After treatment with RA the number of cells at $\mathrm{S}$ phase decreased. These numbers were recovered after three and six days treatment with different amounts of $\mathrm{VH}$.

these reports, where treatment of the normal NT2 cells showed an obvious increase in the rate of proliferation. This potential of VH was further examined on partially differentiated cells to check whether they can revive their cell cycling back to normal. For this the NT2 cells were first forced to partial differentiation by exposing them to RA (Bahrami et al., 2005). As expected these cells lost their cycling efficiency partly, examined either by direct cell counting or flow cytometry, where the number of cells at $\mathrm{S}$ phase of the cell cycling was dropped. After treating the normal NT2 and NT2-RA cells with VH, the number of the cycling cells at $\mathrm{S}$ phase increased. Such increase was translated to an obvious increase in cell proliferation when examined by direct cell counting in this study. However, 

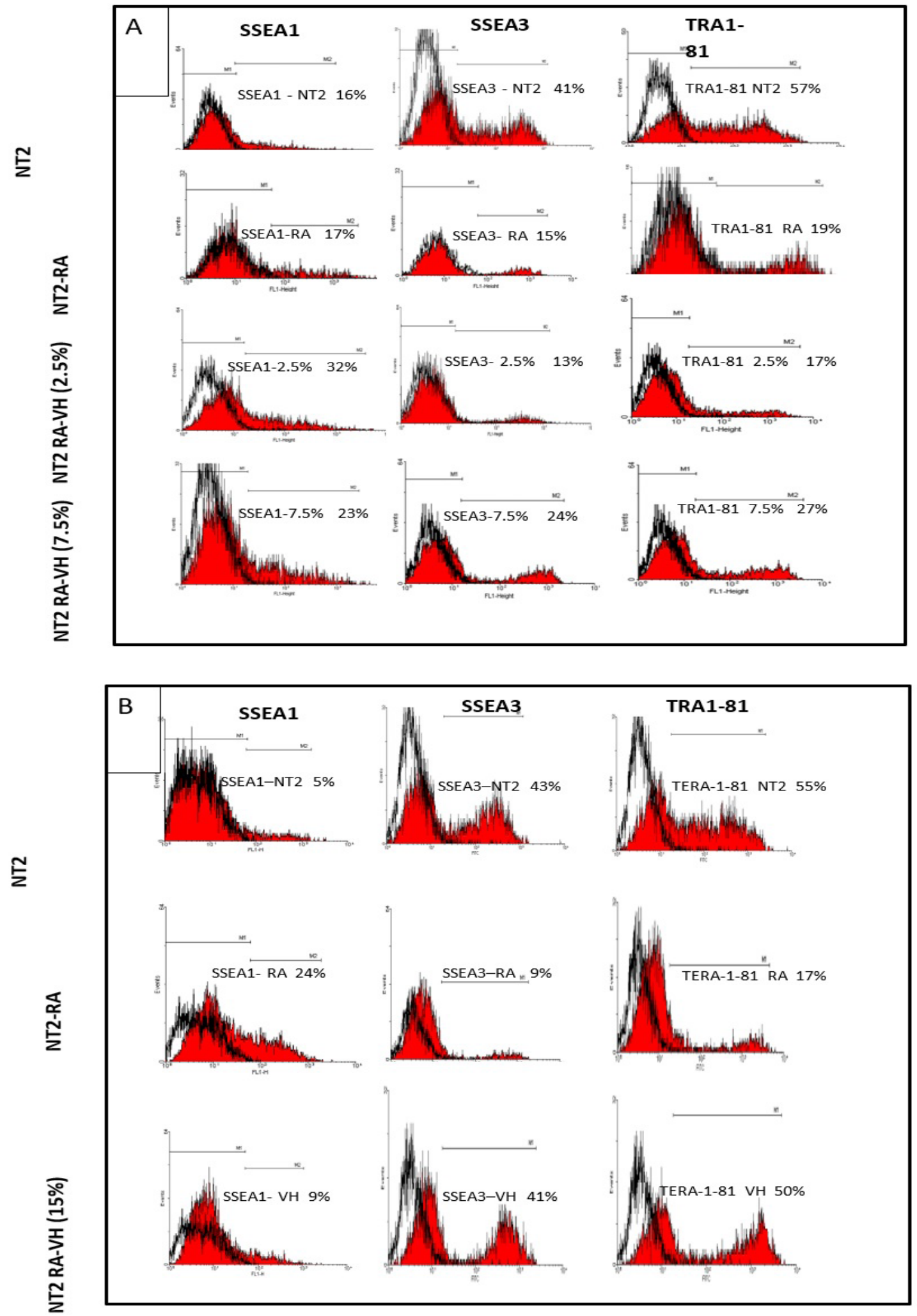

Figure 3. Flow cytometry analysis to assess the level of TRA-81, SSEA1, and SSEA3 cell surface antigens on NT2, NT2-RA, and NT2-RA cells treated with different concentrations of VH for 6 days. (A) NT2-RA cells treated with $2.5 \%$ and $7.5 \%$ VH; (B) NT2-RA cells treated with $15 \% \mathrm{VH}$. 
Table 2. Flow cytometry analysis to assess the level of TRA-81, SSEA1, and SSEA3 cell surface antigens on NT2, NT2-RA, and NT2-RA cells treated with different concentrations of $\mathrm{VH}$ for 6 days.

\begin{tabular}{cccccc}
\hline Variable & NT2 & NT2-RA & NT-RA+VH (2.5\%) & NT-RA+VH (7.5\%) & NT-RA+VH (15\%) \\
\hline TRA1-81 & 57 & 19 & 17 & 27 & 50 \\
SSEA1 & 16 & 17 & 32 & 23 & 9 \\
SSEA3 & 41 & 15 & 13 & 24 & 41 \\
\hline
\end{tabular}

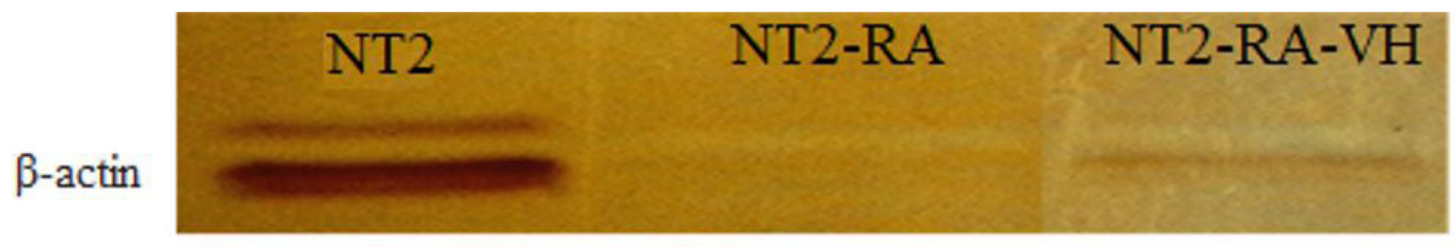

Figure 4. Western blot analysis show that the NT2 cells are known as perfectly positive cells for OCT4 protein expression.

considering the content of $\mathrm{VH}$ in terms of electrolytes and various proteins, based on the results of the present study, it seems that a concentration of $7.5 \%$ is a more appropriate concentration for wound healing and regeneration than a concentration of $15 \% \mathrm{VH}$.

NT2 cells are widely used as model cells for studying the fine changes of cell behaviors regarding self-renewal versus differentiation, because they carry the same stemness properties as embryonic stem cells when it comes to expression of molecular markers such as OCT4 or cell surface antigens. In current study the power of $\mathrm{VH}$ for improvement of the self-renewal property of the cells was also tested based on the changes of the expression of OCT4 protein and cell surface antigens, including SSEA3, SSEA4, TRA1-81 and TRA1-60. RA treatment of the NT2 cells was shown to reduce the expression of all the above mentioned markers as expected (Bahrami et al., 2005). Meanwhile exposure of the NT2-RA cells with VH, at concentration of $15 \%$, proved to reverse the pattern of expression of the markers partly.

The vitreous humor is composed of $99 \%$ water. The remaining components are believed to include mainly hyaluronic acid, salts, glucose, ascorbic acid, and multiple polypeptides and proteins, including albumin, transferrin, IgG, cartilage matrix-like glycoprotein, and others (Rocha et al., 2014). The effect of hyaluronan on proliferation of cord blood progenitor cells is well known (Heldin et al., 2013; Liu et al., 2016). Ascorbic acid, an antioxidant that helps to protect the ocular tissues from free radical attack, is accumulated in the vitreous at a concentration several times higher than that present in plasma (Abdelkawi et al., 2014; Ma et al., 2016). In other attempts it was shown that ascorbic acid increases the proliferation of rat retinal precursor cells in culture conditions (Moteki et al., 2012) and that albumin, a major soluble vitreous protein, augments retinal precursor cell proliferation when used to supplement standard EGFcontaining proliferation medium (Moteki et al., 2012). These findings along with the fact that Vitamin $C$ is considered as small molecule for promotion of stemness state of the mammalian cells in induced Pluripotent Stem cell (iPSc) technology may explain the reason for improvement of the cell proliferation of NT2 cells and self-renewability of the NT2-RA cells by the VH. However fibroblast growth factor is one of the most important factors in vitreous humor. Studies show that these factors are necessary for the natural evolution of the lens (Zheng et al., 2019). Thus, the triple deletion of fibroblast growth factor 1, 2, and 3 genes during the process of lens platelet formation leads to the formation of no visual bubble. Therefore, the presence of fibroblast growth factors and other vitreous molecules are essential in the development of lens growth (Padula et al., 2020). The most important factor in the vitreous family are FGF factors, especially FGF-1 and FGF-2, which cause elongation and structural specialization in cell proliferation (Grigoryan, 2020). According previous studies, these factors are not during changes over the course of life (Grigoryan, 2018). Therefore, longevity will not have much effect on the effectiveness of the vitreous.

Overall, the findings of this study showed that vitreous humor is a rich source that plays an effective role in wound healing in biological models. Therefore, in order to achieve better results, it is suggested that more research be done on different growth factors of vitreous humor, so that they can be considered as appropriate factors.

\section{Conclusions}

We report here a possible mechanism for such effect at cellular level. Based on our data VH seems to be involved on mechanisms improving cell renewal property or even molecular reprogramming of the cells leading to cell dedifferentiation. This hypothesis needs however to be examined in more details at molecular level. 


\section{Acknowledgements}

We would like to thank all people who participate in this study.

\section{References}

ANDREWS, P.W., DAMJANOW, I., SIMON, D., BANTING, G.S., CARLIN, C., DRACOPOLI, N.C. and FOGH, J., 1984. Pluripotent embryonal carcinoma clones derived from the human teratocarcinoma cell line Tera-2. Differentiation in vivo and in vitro. Lab Invest, vol. 50, no. 2, pp. 147-162. PMid: 6694356.

ABDELKAWI, S.A., ABDEL-SALAM, A.M., GHONIEM, D.F. and GHALY, S.K., 2014. Vitreous humor rheology after Nd: YAG laser photo disruption. Cell Biochemistry and Biophysics, vol. 68, no. 2, pp. 267-274. http://dx.doi.org/10.1007/s12013-013-9706-5. PMid:23797611.

BAHRAMI, A.R., MATIN, M.M. and ANDREWS, P.W., 2005. The CDK inhibitor p27 enhances neural differentiation in pluripotent NTERA2 human EC cells, but does not permit differentiation of 2102Ep nullipotent human EC cells. Mechanisms of Development, vol. 122, no. 9, pp. 1034-1042. http://dx.doi.org/10.1016/j. mod.2005.04.011. PMid:16023837.

DEAN, W., 2015. Cellular reprogramming in basic and applied biomedicine: the dawn of regenerative medicine. In: P.J. VERMA and H. SUMER, eds. Cell reprogramming: methods and protocols. New York: Humana Press, pp. 3-13.

EID, W. and ABDEL-REHIM, W., 2016. Vitamin C promotes pluripotency of human induced pluripotent stem cells via the histone demethylase JARID1A. Biological Chemistry, vol. 397, no. 11, pp. 1205-1213. http://dx.doi.org/10.1515/hsz-2016-0181. PMid:27343473.

EMING, S.A., MARTIN, P. and TOMIC-CANIC, M., 2014. Wound repair and regeneration: mechanisms, signaling, and translation. Science Translational Medicine, vol. 6, no. 265, pp. 265sr6. http:// dx.doi.org/10.1126/scitranslmed.3009337. PMid:25473038.

FENG, B., NG, J.-H., HENG, J.-C.D. and NG, H.-H., 2009. Molecules that promote or enhance reprogramming of somatic cells to induced pluripotent stem cells. Cell Stem Cell, vol. 4, no. 4, pp. 301-312. http://dx.doi.org/10.1016/j.stem.2009.03.005. PMid:19341620.

GRIGORYAN, E., 2018. Endogenous cell sources for eye retina regeneration in vertebrate animals and humans. Russian Journal of Developmental Biology, vol. 49, no. 6, pp. 314-326. http:// dx.doi.org/10.1134/S106236041901003X.

GRIGORYAN, E.N., 2020. Potential endogenous cell sources for retinal regeneration in vertebrates and humans: progenitor traits and specialization. Biomedicines, vol. 8, no. 7, pp. 208. http:// dx.doi.org/10.3390/biomedicines8070208. PMid:32664635.

HARA, H., GOTO, T., TAKIZAWA, A., SANBO, M., JACOB, H.J., KOBAYASHI, T., NAKAUCHI, H., HOCHI, S. and HIRABAYASHI, M., 2016. Rat blastocysts from nuclear injection and time-lagged enucleation and their commitment to embryonic stem cells. Cellular Reprogramming, vol. 18, no. 2, pp. 108-115. http://dx.doi. org/10.1089/cell.2015.0084. PMid:26990947.

HELDIN, P., BASU, K., OLOFSSON, B., PORSCH, H., KOZLOVA, I. and KAHATA, K., 2013. Deregulation of hyaluronan synthesis, degradation and binding promotes breast cancer. Journal of Biochemistry, vol. 154, no. 5, pp. 395-408. http://dx.doi. org/10.1093/jb/mvt085. PMid:24092768.

HOCKEMEYER, D. and JAENISCH, R., 2016. Induced pluripotent stem cells meet genome editing. Cell Stem Cell, vol. 18, no. 5, pp. 573-586. http://dx.doi.org/10.1016/j.stem.2016.04.013. PMid:27152442.

JAENISCH, R. and HOCHEDLINGER, K., 2015. Methods for reprogramming somatic cells. United States. Patent US20100144031A1.

KOHLER, G., and MILSTEIN, C., 1975. Continuous cultures of fused cells secreting antibody of predefined specificity. Nature, vol. 256, pp. 495-497.

LI, W., WEI, W. and DING, S., 2016. TGF- $\beta$ signaling in stem cell regulation. In: X.H. FENG, P. XU and X. LIN, eds. TGF- $\beta$ signaling: methods and protocols. New York: Springer, pp. 137-145.

LI, W., ZHOU, H., ABUJAROUR, R., ZHU, S., YOUNG JOO, J., LIN, T., HAO, E., SCHÖLER, H.R., HAYEK, A. and DING, S., 2009. Generation of human-induced pluripotent stem cells in the absence of exogenous Sox2. Stem Cells, vol. 27, no. 12, pp. 2992-3000. PMid: 19839055.

LIU, R.-M., SUN, R.-G., ZHANG, L.-T., ZHANG, Q.-F., CHEN, D.-X., ZHONG, J.-J. and XIAO, J.-H., 2016. Hyaluronic acid enhances proliferation of human amniotic mesenchymal stem cells through activation of Wnt/ $\beta$-catenin signaling pathway. Experimental Cell Research, vol. 345, no. 2, pp. 218-229. http:// dx.doi.org/10.1016/j.yexcr.2016.05.019. PMid:27237096.

MA, N., SIEGFRIED, C., KUBOTA, M., HUANG, J., LIU, Y., LIU, M., DANA, B., HUANG, A., BEEBE, D., YAN, H. and SHUI, Y.B., 2016. Expression profiling of ascorbic acid-related transporters in human and mouse eyesascorbic acid related transporters in human and mouse eyes. Investigative Ophthalmology \& Visual Science, vol. 57, no. 7, pp. 3440-3450. http://dx.doi.org/10.1167/ iovs.16-19162. PMid:27367512.

MIZUTANI, E., TORIKAI, K., WAKAYAMA, S., NAGATOMO, H., OHINATA, Y., KISHIGAMI, S. and WAKAYAMA, T., 2016. Generation of cloned mice and nuclear transfer embryonic stem cell lines from urine-derived cells. Scientific Reports, vol. 6, no. 1, pp. 23808. http://dx.doi.org/10.1038/srep23808. PMid:27033801.

MOTEKI, H., SHIMAMURA, Y., KIMURA, M. and OGIHARA, M., 2012. Signal transduction pathway for L-ascorbic acid-and L-ascorbic acid 2-glucoside-induced DNA synthesis and cell proliferation in primary cultures of adult rat hepatocytes. European Journal of Pharmacology, vol. 683, no. 1-3, pp. 276-284. http://dx.doi. org/10.1016/j.ejphar.2012.02.047. PMid:22429571.

PADULA, S.L., SIDLER, E.P., WAGNER, B.D., MANZ, C.J., LOVICU, F.J. and ROBINSON, M.L., 2020. Lens fiber cell differentiation occurs independently of fibroblast growth factor receptor signaling in the absence of Pten. Developmental Biology, vol. 467, no. 1-2, pp. 1-13. http://dx.doi.org/10.1016/j.ydbio.2020.07.017. PMid:32858001.

PFEIFFER, M.J., ESTEVES, T.C., BALBACH, S.T., ARAÚZO-BRAVO, M.J., STEHLING, M., JAUCH, A., HOUGHTON, F.D., SCHWARZER, C. and BOIANI, M., 2013. Reprogramming of two somatic nuclei in the same ooplasm leads to pluripotent embryonic stem cells. Stem Cells, vol. 31, no. 11, pp. 2343-2353. http://dx.doi.org/10.1002/ stem.1497. PMid:23922292.

RAO, M., MASON, C. and SOLOMON, S., 2015. Cell therapy worldwide: an incipient revolution. Regenerative Medicine, vol. 10, no. 2, pp. 181-191. http://dx.doi.org/10.2217/rme.14.80. PMid:25835482.

ROCHA, A.S., SANTOS, F.M., MONTEIRO, J.P., CASTRO-DE-SOUSA, J.P., QUEIROZ, J.A., TOMAZ, C.T. and PASSARINHA, L.A., 2014. Trends in proteomic analysis of human vitreous humor samples. Electrophoresis, vol. 35, no. 17, pp. 2495-2508. http://dx.doi. org/10.1002/elps.201400049. PMid:24825767.

TAKAHASHI, K. and YAMANAKA, S., 2006. Induction of pluripotent stem cells from mouse embryonic and adult fibroblast cultures 
by defined factors. Cell, vol. 126, no. 4, pp. 663-676. http://dx.doi. org/10.1016/j.cell.2006.07.024. PMid:16904174.

TAKAHASHI, K. and YAMANAKA, S., 2013. Induced pluripotent stem cells in medicine and biology. Development, vol. 140 no. 12, pp. 2457-2461. http://dx.doi.org/10.1242/dev.092551. PMid:23715538.

TOMITA, Y., CAGNONE, G., FU, Z., CAKIR, B., KOTODA, Y., ASAKAGE, M., WAKABAYASHI, Y., HELLSTRÖM, A., JOYAL, J.-S., TALUKDAR, S., SMITH, L.E.H. and USUI, Y., 2021. Vitreous metabolomics profiling of proliferative diabetic retinopathy. Diabetologia, vol. 64, no. 1, pp. 70-82. http://dx.doi.org/10.1007/s00125020-05309-y. PMid:33099660.

WANG, B., PFEIFFER, M.J., DREXLER, H.C., FUELLEN, G. and BOIANI, M., 2016. Proteomic analysis of mouse oocytes identifies PRMT7 as reprogramming factor that replaces SOX2 in the induction of pluripotent stem cells. Journal of Proteome Research, vol. 15, no. 8, pp. 2407-2421. http://dx.doi.org/10.1021/acs. jproteome.5b01083. PMid:27225728.

WANG, H., FENG, L., HU, J.W., XIE, C.L. and WANG, F., 2012. Characterisation of the vitreous proteome in proliferative diabetic retinopathy. Proteome Science, vol. 10, no. 1, pp. 15. http://dx.doi.org/10.1186/1477-5956-10-15. PMid:22390717.

WERNIG, M., MEISSNER, A., FOREMAN, R., BRAMBRINK, T., KU, M., HOCHEDLINGER, K., BERNSTEIN, B.E. and JAENISCH, R., 2007. In vitro reprogramming of fibroblasts into a pluripotent EScell-like state. Nature, vol. 448, no. 7151, pp. 318-324. http:// dx.doi.org/10.1038/nature05944. PMid:17554336.

XU, Y., ZHANG, M., LI, W., ZHU, X., BAO, X., QIN, B., HUTCHINS, A.P. and ESTEBAN, M.A., 2016. Transcriptional control of somatic cell reprogramming. Trends in Cell Biology, vol. 26, no. 4, pp. 272-288. http://dx.doi.org/10.1016/j.tcb.2015.12.003. PMid:26776886.

YANG, J., KLASSEN, H., PRIES, M., WANG, W. and NISSEN, M.H., 2009. Vitreous humor and albumin augment the proliferation of cultured retinal precursor cells. Journal of Neuroscience Research, vol. 87, no. 2, pp. 495-502. http://dx.doi.org/10.1002/ jnr.21873. PMid:18803297.

ZHENG, M., TIAN, C., FAN, T. and XU, B., 2019. Fibronectin regulates the self-renewal of rabbit limbal epithelial stem cells by stimulating the Wnt11/Fzd7/ROCK non-canonical Wnt pathway. Experimental Eye Research, vol. 185, pp. 107681. http://dx.doi. org/10.1016/j.exer.2019.05.021. PMid:31150636. 